\title{
Role of Access to Finance for the Performance of Small and Medium Enterprises in Muhoza Sector, Rwanda
}

Jean Bosco Harelimana*

Ruhengeri Institute of Higher Education, Musanze, Rwanda

\begin{abstract}
Muhoza sector, Musanze District in Northern Province of Rwanda was taken under the study to analyze the role of access to finance for small and medium enterprises (SMEs) performance within a period from 2012-2015. The sample size of the study was 133 SMEs from the total population of 2128 SMEs. In order to achieve the objectives, this study employed a descriptive case study design and the data were collected using questionnaires and interview techniques. Data was analyzed using descriptive statistics and linear multiple regression analysis and then presented in statistical tables. The results show that the factor influencing access to external finance was Simple application procedures for loan with $84 \%$. Also the results confirmed the role of access finance such as improve profitability $(91 \%)$ improve firm efficiency $(87 \%)$, prevent liquidity problems $(72 \%)$, improve firm solvency $(69 \%)$ and increase of assets quality $(64 \%)$. Other role of access to finance by SMEs is to meet expenditures which accounted for 39 percent of the responses. The results confirm the hypothesis because the linear regressions are significant at $p<0.05$. The study conducted a multiple regression analysis from which means all the independent variables have a significant contribution to SMEs. There is therefore the need to design short courses in the area of financial management practices for entrepreneurs, particularly those with lower educational background as education is an important factor in accessing finance. Size of the firm was also found to be a significant factor affecting access to finance and therefore small firms should come together to form bigger firms in order to attract sources of finance. Banks and other financial providers should have a department solely devoted to the financing needs of SMEs and develop products purposely for SMEs which contribute to economic development of Rwandans society.
\end{abstract}

Keywords: Finance; Population; Regression

\section{Introduction}

The Small and Medium Enterprises (SMEs) sector is internationally known as the driving force in economic growth and employment creation. SMEs play an important role in creating employment and wellbeing [1]. Central to the growth of any economy is the development of a vibrant SME sector which is the key to resolving many societal challenges, including unemployment. The raise of SMEs is viewed as an important issue in many countries, because it plays significant responsibility in providing further employment and conversion of economy $[2,3]$.

SME sector performance is sine qua non to the performance of the nation. The vast majority of firms worldwide are SMEs, and they serve as a breeding ground for entrepreneurs and a provider of solutions to address the problems of unemployment in all consuming labours and promoting marketing growth [4]. The importance of SMEs is stimulating growth, creating social cohesion, contributing to gross domestic product (GDP) and generating income, increase in employment, output, innovation in technology and lifting up in social position which finally contribute to reduction in poverty in the country. Small and Medium Scale Enterprises have been acknowledged to have a prodigious potential for sustainable Development [5].

The Government of Rwanda (GoR) has a vision to become a middle-income country, in order to achieve this goal the medium term Economic Development and Poverty Reduction Strategy (EDPRS) states that it must achieve an annual GDP growth rate of $8.1 \%$ and increase off-farm employment to $30 \%$ [6] Small and Medium Enterprises (SMEs) and micro enterprises in Organization for Economic Cooperation and Development (OECD) countries account for over $95 \%$ of all firms, $60-70 \%$ of employment and $55 \%$ of GDP and create the majority of new jobs, indicating the impact SMEs have on employment. In contrast, currently over $80 \%$ of Rwanda's populations are engaged in agricultural sector. The SME sector, including formal and informal businesses, comprises $98 \%$ of the businesses in Rwanda and $41 \%$ of all private sector employment $[6,7]$.

All around the world governments are supporting and promoting entrepreneurship. However main criteria to start-up and maintain business are finance, the finance is not unique resource, but rather source of company's sustainability [8]. The finance or money is most liquid asset in the world, which can be used in different ways: such as investments in company or innovation, spend for private use, become independent or just survive tough financial period [9]. For the growth of small and medium-size enterprises (SMEs) financial access is critical [10]. It allows entrepreneurs to innovate, improve efficiency, expand to new markets, and provide millions of jobs. Yet, in developing countries, the majority of SMEs are unable to acquire the financing they need to reach their potential.

According to ABDG [11], one of the factors limiting the survival and growth of small and medium enterprises (SMEs) is non-availability of debt financing. However access to finance has been identified as the most important problem that SMEs face. Lack of access to financing is consistently cited by SMEs as one of the main barriers to growth.

There is considerable evidence to support the contention that SMEs, in particular, face a number of obstacles and problems in accessing finance, mainly because of their limited resources and perceived risk

*Corresponding author: Jean Bosco Harelimana, Ruhengeri Institute of Highe Education, Musanze, Rwanda, Tel: 250788903032; E-mail: harelijordan@yahoo.fr

Received December 29, 2016; Accepted January 17, 2017; Published January 22, 2017

Citation: Harelimana JB (2017) Role of Access to Finance for the Performance of Small and Medium Enterprises in Muhoza Sector, Rwanda. Bus Eco J 8: 279. doi: 10.4172/2151-6219.1000279

Copyright: ( 92017 Harelimana JB. This is an open-access article distributed unde the terms of the Creative Commons Attribution License, which permits unrestricted use, distribution, and reproduction in any medium, provided the original author and source are credited. 
by lenders [12]. The difficulty in accessing finance has been described as the most significant constraint facing SMEs in both developed and developing countries $[10,12]$. According to Kale et al. lack of financial access is argued to be one of the most binding constraints for small firms, especially in developing countries. In a survey conducted by Beck et al. [10], access to and cost of finance were ranked among the most constraining features of the business environment of SMEs. According to Frimpong, the issue of access to finance by firms in general, and the theoretical recognition that financing gap can exist for firms, can be traced back to the theory of imperfect information in capital markets by La Porta et al. [13] Small and medium enterprises find that it is difficult to obtain source of finance in the form of debt and equity.

From the foregoing background of the study, many studies have shown that access to finance remains a major constraint to SMEs $[5,14,15]$. In Rwanda, there were a number of informal, semi-formal and formal interventions undertaken to provide financial support to SMEs. However a number of surveys [6,7] indicate that access to finance continues to pose a major challenge to Small and Medium Enterprises' operations in the country.

It therefore appears that access to finance by SMEs is constrained by lack of investment readiness, unwillingness of financial institution to finance SMEs due to their age, size, Legal Form, and asset tangibility; this can be accounted for increased liquidation leading to closure of business. Many SMEs have faced the same challenges but they are specific internality such as lack of investment readiness, unwillingness of owners to seek external equity and debt finance and lack of understanding about what equity investors are looking for or how to market their businesses to potential investors. In addition to government and non-governmental organizations providing funding for SMEs; access to finance continues to be a major constraint to SMEs in Rwanda. The prayerful question is therefore, how does access to finance by SMEs affect their performance in Rwanda? This study therefore sought to investigate the role of access to finance for the performance of Small and Medium Enterprises (SMEs) in Muhoza sector for a period of (2012-2015)

\section{Objectives}

The general objective of this study is to analyse the role of access to finance for the performance of small and medium enterprises in Rwanda. The specific objectives are:

- To assess the determinants of access to finance by SMEs in Muhoza Sector.

- To analyze the indicators of financial performance of SMEs in Muhoza Sector.

- To measure the relationship between determinants of access to finance and indicators of financial performance of Small and Medium Enterprises at Muhoza Sector.

\section{Literature Review}

According to Weston and Brigham, access to finance is the ability of individuals or enterprises to obtain financial services, including credit, deposit, payment, insurance, and other risk management services. Those who involuntarily have no or only limited access to financial services are referred to as the unbanked or under banked, respectively.

According to Palm [16], performance measurement is defined as process widely used by production and operation management that aims at improving production line toward profit maximization and achievement of organizational objectives. According to Chary [17], the improvement are based on individual, group, and whole the organizational stakeholders. A set of measures that help managers evaluate a company's economic performance and spot the need for changes in operations (KPI) includes financial measures (objective) and non financial metrics (subjective).

A financial statement is a collection of data that is organized according to logical and consistent accounting procedures. Its purpose is to convey an understanding of some financial aspects of a business firm [18]. It may show a position of a period of time as in the case of a Balance Sheet, or may reveal a series of activities over a given period of time, as in the case of an Income Statement [9].

\section{Balance sheet}

The Balance Sheet is a statement which shows the financial situation (position) of the firm at a given point of time. It provides a snapshot that may be regarded as a static image [17] "Balance sheet is a summary of a firm's financial position on a given date that shows Total assets $=$ Total liabilities + Owner's equity (IAS1).

\section{Income statement}

Frank and Alan [9], stated that the Income statement is a statement which shows the performance of the firm over a period of time. However it indicates the summary of a firm's business revenues and expenses over a specified period, ending with net income or loss for the period."

\section{Cash flow statement}

It is a statement which shows the cash earned in the business and that out of it means cash inflows and cash outflows [9]. The statement is prepared to show the amount of cash that is available at the end of accounting period [9].

\section{Methodology}

The study is analytical, historical and empirical in nature. Different methods have been used to help achieve the objective of the study. In this section, we provide the sources of data, techniques, methods and the model used to arrive to decision making.

\section{Data collection}

The study makes the use of primary and secondary data in collecting data. Techniques such as interview, questionnaires, documentation and other techniques were employed in this study. A questionnaire was designed for 133 managers and owners of selected SMEs in Muhoza sector from 2128 total population. Sample size makes this research credible for the reason that the sample would be representative of the whole population and that the findings would be consequently exact. Simple random sampling techniques was used to select a random representative sample of this study [19]. References have been made to textbooks, journals, newspapers and other published literature, electronic journal and the internet that provides as valuable reference. Archival method was important for this research. Quantitative or statistical and qualitative method of data analysis also both were used in this study. After the data collected were organized, edited and coded, quantitative data were entered into Statistical Package for Social Science (SPSS) and were analyzed using descriptive statistics. Closed ended questionnaire and open ended questionnaire were analyzed using SPSS. The SPSS was also used to determine frequencies in order to discover the degree of occurrence to each variable. 


\section{Models and techniques}

Linear function model has been formulated to help assess the impact of the extraneous variables and independent variables on the dependent variables. To measure the relationship between access to finance and performance of SMEs, regression analysis was used to determine this relationship. The correration matrix extracted using SPSS show the correlation between roles of access to finance to SMEs performance indicators.

In doing so, the regression model below was used: $y=\beta_{0}+\beta_{1} x_{1}+\ldots \ldots \ldots+\beta_{5} x_{5}+\varepsilon$. Where $y$ represents the dependent variable means performance of SMEs such as current ratio, return on assets, return on equity, operating expense ratio and debts to assets ratio; and $\beta_{0}=$ Constant term $\beta_{(1-5)}=$ represent the model parameters or coefficients; $x_{1}=$ Low costs of accessing finance, $x_{2}=$ low interest rates, $\mathrm{x}_{3}=$ simple application procedures for loan, $\mathrm{x}_{4}=$ simple collateral requirements and $\mathrm{x}_{5}=$ guarantees and $\varepsilon=$ error terms.

\section{Findings and Results}

In this work, the number of respondent comprised 133 managers of SMEs in Muhoza, Sector Musanze District where 64\% are males and $36 \%$ were female. Within 133 respondents, $33 \%$ have completed primary education while $38 \%$ have completed secondary education, $6 \%$ were uneducated, $13 \%$ have completed vocational, technical or commercial education while only $10 \%$ have completed the university studies. The results show that the entrepreneurs (owners) in Muhoza sector were dominated by $71 \%$ by those who studied in primary schools and secondary schools and uneducated are $6 \%$ only which is a good indicators of education in Muhoza sector.

The results shows that within Muhoza sector young generation has not forecast in SMEs creation, while between 37 and 46 is the most age of SMEs creation. Regarding economics, 29, 18, 13 percent of SMEs in the study were in the agriculture, forestry, wholesale and retail trade, accommodation and food processing services respectively $11 \%$ were information and communication, $9 \%$ were other services and also $6 \%$ were financial and insurance. It is not surprising that the sub-sectors with least representation were manufacturing, professional services and health and education with $4 \%, 3 \%, 3 \%$ respectively. The reason is that these economic sectors are high capital demanding and therefore few people can invest into those activities. The result shows that $51 \%$ of most of enterprises that operate in Muhoza sector are in agriculture, wholesales and trade while manufacturing in Muhoza sector is one of least sector that operated in muhoza sector with $4 \%$. It further show that commodities traded in SMEs located in Muhoza sector was from foreign place.

\section{Access to finance}

The sources of finance were mainly classified as internal (cash in hand and retained earnings) and external (finance in form of equity and finance in form debt). The results show that almost a half of the firms (38.8\%) operate their enterprises using both external and internal sources of finance and only $25.5 \%$ operates with external sources while the remaining $35.5 \%$ operates within internal sources. The results further indicate that most of SMEs in Muhoza used internal finance. A $100 \%$ of respondent agreed that they use external sources to improve their operation from the understudied period. This indicate that external finance is very important in financing SMEs operations.

One of the most commonly used type of external finance by more than a half of firms was loan from the bank (87.9\%). In the literature,
SMEs seek finance for several reasons but some challenges were obstacles to access for it. Many SMs in the study applied for external finance but not all of them were successful. $61.3 \%$ of those who applied for external funding failed to get it was lack of collateral, this is followed closely by the fact that the entrepreneurs are new business start-up (58.8\%) and have insufficient information (47.5\%). Other reasons why some SMEs never sought external finance were that they lack experience (37.5\%); they could not meet requirement (16.3.0\%); while some of them was not give their reasons (28.8\%). Give an indication of how wealthier the shareholder has become as a result of the investment over a specific time. It is in that framework the researcher formulated questions to SMEs manager operating in Muhoza sector to assess the role of access to finance on their performance.

The results indicated $41 \%$ prepare financial information in the form of income statement, statement of financial position, statement of cash flow, variance analysis or financial ratios. However, majority of the SMEs in the study $49 \%$ did not prepare any form of financial information. This result has not good perspective on accessing finance as the financial information affect accessing to finance. Financial information (income statement, statement of financial position, cash flow statement, financial ratio, and business plan) is one of factors to access finance. The findings from shows that statement of financial position is used with $92 \%$ and it followed by income statement and business plan with $86 \%$ and $78 \%$ respectively. The two financial information classified as the least was financial ratios and cash flow statement with $38 \%$ and $49 \%$ respectively. The reason may be because entrepreneurs do not have the expertise required in preparing and using these pieces of financial information. The results further indicate that statement of financial position and income statement are mostly used because they provide the picture of assets and liabilities and also indicate profit $[9,16,17]$.

\section{Determinants for access to finance}

A great number of determinants may affect the desire of SMEs to access external finance. The results shows that simple application procedures for loan with $84 \%$. followed by collateral requirements with $80 \%$, low costs of accessing finance with $74 \%$ and low interest rates which had $68 \%$. Guarantee from government with a $51 \%$ was the least factor that influencing SMEs access to external finance. This shows that all the determinants of external finance were considered relevant in accessing external finance.

Writings stated that because of uncertainty and risk financial institution before providing financial services to their clients they considered many factors. According to the table calculated above the first factors considered is financial management practices which encompasses $71 \%$ followed by firm characteristics which encompasses $55 \%$ and finally by entrepreneur characteristics which encompasses $55 \%$. The results further indicate that the most SMEs in operating well are the first one to attract financial services providers.

\section{Financial ratio analysis}

Return on assets: The results show that the two SMEs have good results because in MPEse the profits of each year earned from average total assets means that 100 franc of average total assets generates $21.20 \%, 25.26 \%, 25.23 \%$ and $29.75 \%$ as profit plus interest in 2012 , 2013, 2014 and 2015 respectively while in Family Bread Bakery the results are $52.18 \%, 49.21 \%, 65.48 \%$ and $58.46 \%$ profit plus interest in the year of 2010, in 2011 and 2013, 2014 and 2015.

Return on equity: The results show that the two SMEs have good 
results because in MPEse the profits of each year earned from average total equity means that 100 franc of average total equity generates $84.98 \%, 95.44 \%, 99.42 \%$ and $93.68 \%$ as profit in 2012, 2013, 2014 and 2015 respectively while in Family Bread Bakery the results are $68.70 \%$, $58.03 \%, 74.63 \%$ and $65.74 \%$ profit in the year of 2010, in 2011 and 2013 , 2014 and 2015.

Current ratio: The current ratio of the two SMEs as tabulated above shows the liquidity of 1.5 times in 2012, 1.089 times in 2013, 1.30 times in 2014 and 1.30 times in 2015for MPEse; while for Family Bread Bakery are 3.38 times, 3.17 times, 2.30times and2.31times in 2012, 2013, 2014 and 2015 respectively. Results show an increase in the liquidity from 2012 to 2014 and a decrease in the liquidity in 2015 for MPEse while for Family Bread Bakery there is a decrease from 2012 t0 2014 and increase in 2015.

Debts to assets ratio: Debt to asset ratio has been decreased from 2012 to 2015 means $76.19 \%, 73.41 \%, 69.67 \%$ and $68.40 \%$ respectively in MPEse. While in Family Bread Bakery the results show a decreased in 2012 to 2015 means $19.50 \%, 15.15 \%, 12.72$ and $12.22 \%$ percent respectively. Those results therefore indicate improvement from 2012 to 2015 in MPEse only.

Equity to assets ratio: Equity to asset ratio have been increased from 2012 to 2015 means $23.80 \%, 26.58 \%$, and $30.32 \%$ and $31.59 \%$ respectively in MPEse. While in Family Bread Bakery the results show an increase in 2012 to 2015 means $80.49 \%, 84.84 \%, 87.27$ and 87.31 percent respectively.

Operating expense ratio: The results revealed that operating profit ratio decrease from 2012 to 2104 means 29.49\%, 26.04\%, and 20.50\% respectively while in 2015 has been increased to $21.51 \%$ in MPEse. In Family Bread Bakery the results show increase in 2012 to 2013 means $12.62 \%$ to $12.75 \%$ respectively and in 2014 to 2015 means 12.06 to 12.29 percent respectively.

The role of accessing finance for performance of SMEs: The major reasons why firms sought external finance were to improve profitability (91\%) improve firm efficiency $(87 \%)$, prevent liquidity problems (72\%), improve firm solvency (69\%) and increase of assets quality $(64 \%)$. Other reason why SMEs sought external finance is to meet expenditures which accounted for 39 percent of the responses. As asserted by different literatures in every organization the overall aim is to make profit [17]

\section{Relationship between access to finance and SSMEs performance}

As shown above, access to finance have as important of preventing liquidity problem, improving profitability, meet recurrent expenditures, improve firm solvency, improve efficiency and an increase of assets quality.

The $R$-square was used as test for model fitness. The F-test was carried out to test the significance of the regression model in predicting the dependent variable (performance of SMEs). From the results, it was found that the four independent variables (Low costs of accessing finance, low interest rates, simple application procedures for loan, simple collateral requirements, and guarantees moderately predict the performance of SMEs (adjusted $R$ squared=.686). That means the model explains $68.6 \%$ the variance in the performance of SMEs; $32.4 \%$ of variations are brought about by factors not captured in the objectives. Therefore, further research should be conducted to investigate the other factors $(32.4 \%)$ that affect performance of SMEs. The regression equation appears to be very useful for making predictions since the value of $R^{2}$ is close to 1 .

The findings shows that the null hypothesis was rejected because the linear regression $F$-test results $(F=8.741$; and $5 \mathrm{df})$ are significant at $p<0.05$. Therefore, the null hypothesis $\left(\mathrm{H}_{\mathrm{o}}\right)$ was rejected and concluded that the regression model linearly explains the performance of SMEs. Therefore, the study accepted the alternative hypothesis.

$\mathrm{H}_{\mathrm{al}}$ : There is a relationship between low costs of accessing finance and performance of SMEs;

$\mathrm{H}_{\mathrm{a} 2}$ : There is a relationship between low interest rates and performance of SMEs;

$\mathrm{H}_{\mathrm{a} 3}$ : There is a relationship between simple application procedures for loan and the performance of SMEs;

$\mathrm{H}_{\mathrm{a} 4}$ : There is a relationship between simple collateral requirements and the performance of SMEs and

$\mathrm{H}_{\text {a5: }}$ There is a relationship between guarantees and the performance of SMEs.

The study conducted a multiple regression analysis so as to determine the regression coefficients $(\beta)$ which shows that $\beta_{0}=1.138$ and which means that all the independent variables low costs of accessing finance, low interest rates, simple application procedures for loan, simple collateral requirements, and guarantees from government have an a significant contribution to SMEs performance even if the $\mathrm{x}$ variable equal to zero means $\mathrm{Y}=1.138$ and according to table the model equation become $\mathrm{Y}=1.138+0.258 \mathrm{X}_{1}+0.367 \mathrm{X}_{2}+0.423 \mathrm{X}_{3}+0.157 \mathrm{X}_{4}+0.34$ $5 \mathrm{X}_{5}$.

The results reveal that SMEs were constrained some challenges which involve bankruptcy or/and inefficiency performance in their operations. The researcher concludes that there is positives relationship between access to finance and performance of SMEs in Muhoza sector as indicated.

\section{Conclusions}

Small and Medium Enterprises (SMEs) have been accepted as the engine of economic growth and for promoting equitable development. Without financial sources SMEs can't acquire or absorb new technologies nor do they expend to compete in global markets or even strikes company linkages with larger companies. The results revealed that 95.7 level of significance present the change in liquidity, profitability, efficiency, increase in assets value, increase in employee salaries, and that is positively and significantly related to the change in costs of accessing finance, interest rates, application procedures for loan, collateral requirements, and guarantees from government and other factors not studied in the study. Though access to finance plays a major role in the performance of SMEs it continues to be a major problem that SMEs face in their operations. The study concludes that SMEs should be sensitized about funding programs and financial schemes provided by the government and private sector and that public and private sectors put in place funding programs and financial schemes to assist SMEs.

\section{Recommendations}

After analysis, it is suggested that SMEs should incorporate good financial management practices such as preparation and usage of financial information in their operations, preparation of business plan, and the well using of working capital management. Because education 
Citation: Harelimana JB (2017) Role of Access to Finance for the Performance of Small and Medium Enterprises in Muhoza Sector, Rwanda. Bus Eco J 8: 279. doi: 10.4172/2151-6219.1000279

Page 5 of 5

and experience of the entrepreneur were found to significantly impact access to finance, therefore the managers need to design short courses in the area of financial management practices for entrepreneurs, particularly those with lower educational background as education is an important factor in accessing finance. Size of the firm was also found to be a significant factor affecting access to finance and therefore small firms should come together to form bigger firms in order to attract sources of finance. Government of Rwanda should be directly involved to help eliminate the financing gap faced by SMEs through direct government interventions through public banks, credit guarantee schemes and other forms of subsidized financing

For further research, one could determine if the findings of this research are consistent across different sectors. Since the study concentrated on SMEs in Muhoza sector only, a further research into other sectors will throw more light on the findings of this study. In addition, there is the need to duplicate the research in other parts of Rwanda to confirm if the results of this research can be generalized across the whole country. Though the study found relationship between the variables tested and access to finance, the model in all cases was not able to give a $100 \%$ prediction. This means that there are other equally important variables that were not considered in this study.

\section{References}

1. Staley E, Morse R (1965) Modern Small-Scale Industry for Developing Countries, McGraw-Hill.

2. Harash E, Al-Tamimi K, Al-Timimi S (2014) The Relationship between Government Policy and Financial Performance: A Study on the SMEs in Iraq. Journal China-USA Business Review 13: 290-295.

3. Harrash E, Al-Tamimi K, Al-Tamimi S (2013) The Influence of Finance on Performance of Small and medium Enterprises (SMES). International Journal of Engineering and Innovative Technology 4
4. European Commission (2001) Enterprises' access to finance. Commission Staff Working Paper, Brussels.

5. WORLD BANK GROUP. (2010). South Africa: Improving the Business Environment for job Creation and Growth. Report No. 55699 -ZA

6. Minicom (2010) Small and Medium Enterprises (SMEs) Development Policy. Kigali.

7. OECD (2011) Bank Competition and Financial Stability Paris: OECD Publications.

8. Ciaran M, Bhaird M (2010) Resource Small and Medium Sized Enterprises. Physica-Verlag.

9. Frank M, Goyal V (2003) Testing the Pecking Order Theory of Capital Structure. Journal of Financial Economics 67: 217-248.

10. Beck T, Demirgüç-Kunt A, Maksimovic V (2005) Financial and Legal Constraints to growth. The Journal of Finance 9: 137-177.

11. ABDG (2011) African Economic Outlook, Kigali.

12. Chong HG (2008) Measuring performance of small-and-medium sized enterprises: the rounded theory approach. Journal of Business and Public Affairs 2: 1-10.

13. La Porta R, Lopez-de-Silanes F, Shleifer A, Vishny R (1997) Legal determinants of external finance. Journal of Finance 52: 1131-1150.

14. OECD (2006) Financing SMEs and Entrepreneurs. OECD Observer.

15. OECD (2006) The SME Financing Gap. Theory and Evidence, Paris.

16. Palm T (2008) Performance assessment and authentic assessment: $A$ conceptual analysis of the literature. Practical Assessment, Research \& Evaluatio 13: 1-13.

17. Chary NS (2008) Production and operation management, McGraw-Hill New.

18. Pandey IM (2009) Management accounting, Vikas Puplishing Housing House.

19. Andrew AB (2008) Research design, and sample size, Routledge, London. 